\title{
From Squatter Slums to Modelled Dwellings in Anthropocene: Bhubaneswar, India
}

\author{
Saswat Mishra, Gopal Ch. Sahoo, Siba Prasad Mishra, Kumar Ch. Sethi, Mohammed Siddique
}

\begin{abstract}
Slums, the poor men paradise, are an informal settlement in Cosmo polis but part to the urban development process. Anthropocene has summoned exodus from rural to urban for food, family education and livelihood. Bhubaneswar, the capital city Odisha was established in 1949 with zero slums till1960's, now has about 436 slum clusters in 67 wards with 304140 slum dwellers comprising $34.30 \%$ of the total population. After declaration as smart city, 2015, inter alia initiatives are taken by federal bodies for the development and resettlement of shantytown dwellers to make it slum less. The Kargil slum is significant due to its positioning, profession and living standards of inhabitants in the heart of the metropolis between airport and EC rail lines needs immediate resettlement. Present work pictures survey of slum in-situ using GIS and total station for demography, sex ratio and socio-economic status. About 1000tenements in 25blocks over an area of 6.23Acres in the outskirt shall be accommodated in $G+4$ buildings. The geotechnical and ground water studies of the new housing area have been done. The design, drawing and scheduling by using Building Information Modelling (BIM) by Auto Cad, and DASSULT software, MS Office, MS Project, E-tabs, Safe, and $D$ modelling by Sketch up. The scheduled period of completion from land acquisition to final handing over shall be 40months at an affordable cost of $400 \mathrm{~K}$ to $500 \mathrm{~K}$ INR per tenement.
\end{abstract}

Keywords: Advanced Survey, BIM Architecture, GIS Housing Scheme, Resettlement, Slum.

\section{INTRODUCTION}

According to census of India, US-3 and Slum Area I\&C Act, 1956, defines a slum area as cluster of informal settlements or unplanned colonies unfit for human occupancy due to disrepair, congestion, faulty activities incapable to provide congested dwellings deprived of sanitation, zigzag roads, lack of light, ventilation and sanitation amenities or amalgamation of them which are harmful to living standards, security, safety, healthiness and morals. The growth of slums

Revised Manuscript Received on February 05, 2020.

* Correspondence Author

Saswat Mishra, National Institute of Construction Management and Research. New Delhi, India. Management, Odisha, India.

Siba Prasad Mishra*, Centurion University of Technology and Management, Odisha, India.

Kumar Charan Sethi, Centurion University of Technology and Management, Odisha, India.

Mohammed Siddique, Centurion University of Technology and Management, Odisha, India.

(C) The Authors. Published by Blue Eyes Intelligence Engineering and Sciences Publication (BEIESP). This is an open access article under the CC BY-NC-ND license (http://creativecommons.org/licenses/by-nc-nd/4.0/)
Gopal Ch. Sahoo, Centurion University of Technology and

in statutory towns (>50000 people) in the heart and suburbs of the city., Industries growth also urges large scale migrants from rural to urban for food, modern living, health, education and proximity of amenities. Old cities has exhausted to expand horizontally so vertical cities are upcoming as satellite cities with onset of Anthropocene epoch in India (1945 onwards).The slums are part to these development processes and unavoidable in India. The informal dwellings called slums developed by EWS (Economically weaker section) by encroaching vacant areas, water bodies or sides of the roads and adjacent to multistoried developments.

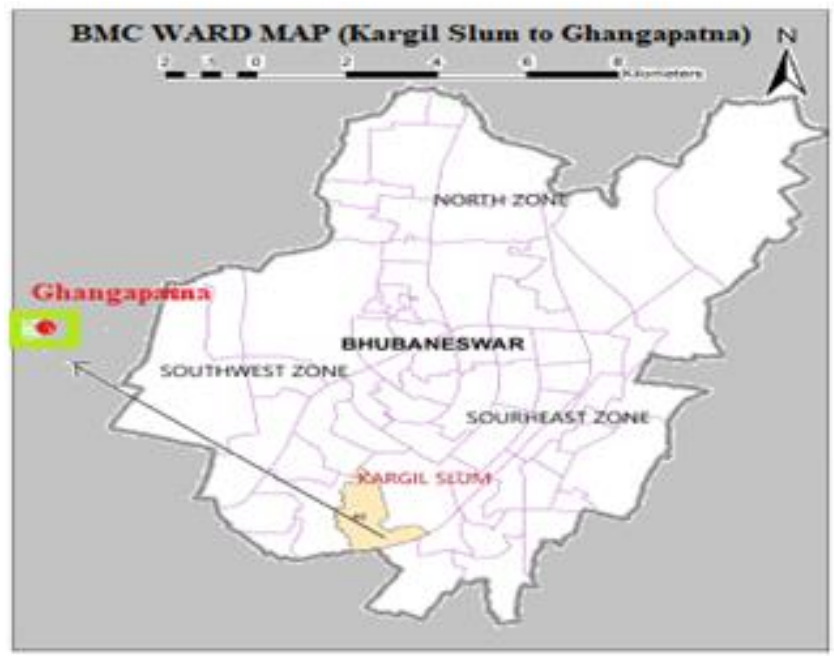

Fig.1: Index map of the study area: Kargil Basti to Ghangapatna Area

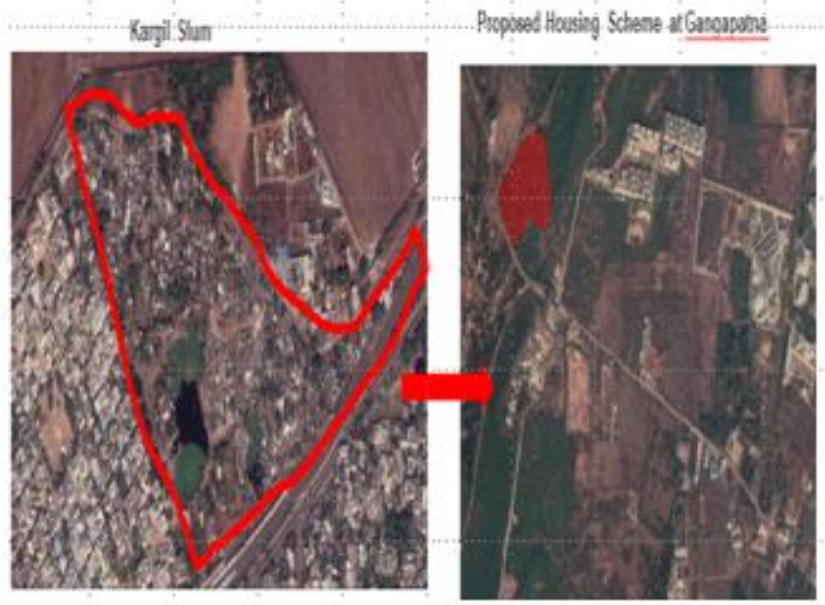

Fig 2: Present populous Kargil slum and the proposed housing scheme at Ghangapatna 
These slums were categorized under recognized, notified and identified and the other way of classification is authorized, unauthorized and identified in India. Nallathiga R. K. et al, 2019[1]reported that, the high cost of housing is sky touching in urban areas that they are difficult for MIG (medium income)group, far reach from LIG (lower income) group and almost impossible for EWS (Economically weaker) group under building by laws in metro cities.

\section{A. Urban population India:}

India has the second largest urban population in the world.
Urban population exceeded rural from 2009, though India is an agri-based country Hind man M et al., 2015[2]. Population wise slum of the state to the India's population Maharashtra is the highest (18.09\%) followed by Andhra Pradesh (AP undivided) and West Bengal (WB).The slum residents have significant contribution to urban economy and development as industrial workforce, construction workers, domestic assistance, rag-pickers, vendors and in many minor professions which is essential (Moore 2017[3]).The status are in Table 1.

Table 1: Status of state wise major slum population (>10\%) of India (2011, census data)[4]

\begin{tabular}{|c|c|c|c|c|c|c|}
\hline States of India & Statuary Town & $\begin{array}{l}\text { slums } \\
\text { Towns }\end{array}$ & $\begin{array}{l}\text { \%slum } \\
\text { state }\end{array}$ & $\begin{array}{ll}\text { Total } & \text { slum } \\
\text { Households } & \\
\end{array}$ & $\begin{array}{ll}\begin{array}{l}\text { Slum } \\
\text { (Identified) }\end{array} & \text { people } \\
\end{array}$ & $\begin{array}{l}\% \text { State to India } \\
\text { in slum }\end{array}$ \\
\hline Undivided AP & 125 & 125 & 361 & 2421268 & 971608 & 15.55 \\
\hline Bihar & 139 & 88 & 10.53 & 194065 & 1237682 & 1.89 \\
\hline Chhattisgarh & 168 & 94 & 31.98 & 395297 & 420426 & 2.9 \\
\hline Delhi & 3 & 22 & 10.91 & 383609 & 1785390 & 2.73 \\
\hline Haryana & 80 & 75 & 18.8 & 325997 & 1647393 & 2.54 \\
\hline Jammu and Kashmir & 86 & 40 & 19.28 & 96990 & 362504 & 1.01 \\
\hline Karnataka & 220 & 206 & 13.93 & 72877 & 573545 & 5.03 \\
\hline MP & 364 & 303 & 28.35 & 1117764 & 5688993 & 8.69 \\
\hline Maharashtra & 256 & 189 & 23.32 & 2449530 & 4653331 & 18.09 \\
\hline Mizoram & 23 & 1 & 13.74 & 16240 & 78561 & 0.12 \\
\hline Nagaland & 19 & 11 & 14.42 & 15268 & 34075 & 0.13 \\
\hline Odisha & 107 & 76 & 22.28 & 350306 & 747566 & 2.38 \\
\hline Puducherry & 6 & 6 & 16.95 & 35070 & 144573 & 0.22 \\
\hline Punjab & 143 & 73 & 14.04 & 296482 & 479517 & 2.23 \\
\hline Rajasthan & 185 & 107 & 12.13 & 383134 & 2068000 & 3.16 \\
\hline Sikkim & 8 & 7 & 20.43 & 8612 & 31378 & 0.05 \\
\hline Tamil Nadu & 721 & 507 & 16.61 & 1451690 & 1278673 & 8.85 \\
\hline Tripura & 16 & 15 & 14.54 & 16372 & 15744 & 0.21 \\
\hline Uttar Pradesh & 648 & 293 & 14.02 & 992728 & 999091 & 9.53 \\
\hline Uttara Khand & 74 & 31 & 15.99 & 89398 & 249631 & 0.74 \\
\hline West Bengal & 129 & 122 & 22.06 & 1393319 & 2665824 & 9.8 \\
\hline India & 4041 & 2613 & & 12506016 & 654946604 & 17.4 \\
\hline
\end{tabular}

\section{B. Status of slum population Odisha:}

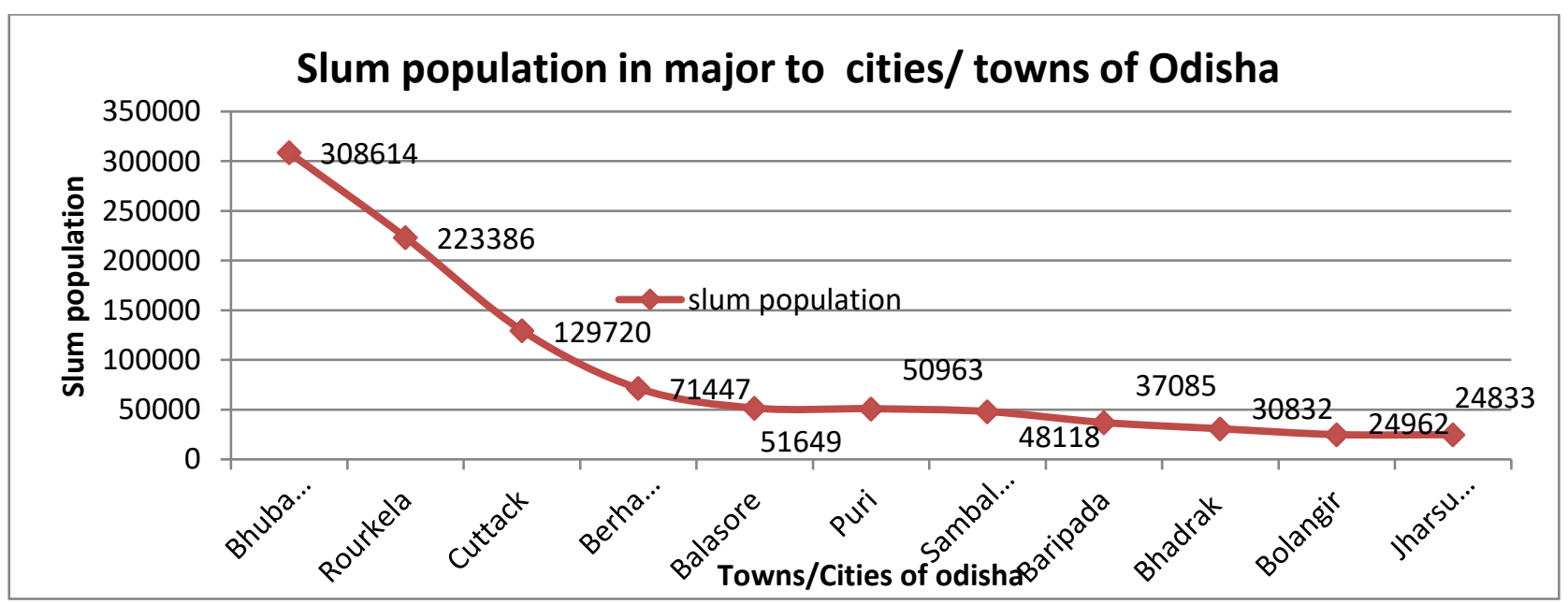

Fig. 3: Top order population wise major 11 slum cities/towns of Odisha (GOO NUHM Data) 


\section{Slum status of Bhubaneswar:}

The novice capital city, Bhubaneswar (BBSR) is one among the official, business, educational, medical \&tourism hub of the Odisha state, housing many IT,\&BPM corporate organizations. Bhubaneswar (BBSR), started as capital city of Odisha from 1949 as a tier-2 city. The city was designed over a cluster of villages by Otto Konigsberger (1946), Bhubaneswar, along with Chandigarh and Jamshedpur. The 70 years old Bhubaneswar City started with 16500 people and zero slums till 1961 within an area of $20.09 \mathrm{Km}^{2}$ (BBSR NAC), which took a higher growth rate during 1970's @131. 41\%, in 1980’s@171.07\% and during 1990’s@107\% and in 2019 it is about one million. The number of wards in BMC was 67according to 2011 census but with city sprawl the number of wards has increased to 81.The city has scope to grow both horizontally and vertically. There has been continuous migration from till date from 16500 people, population density 633per $/ \mathrm{km}^{2}$ in $20.09 \mathrm{Km}^{2}$ area (in a NAC) in 1951 to about one million people, population density 2131 per $/ \mathrm{km}^{2}$ in $186 \mathrm{~km}^{2}$ as projected from census report 2011 . The urban agglomeration has increased rate of migration from rural areas of Odisha and other states. The slum statistics is given in Fig.1, Fig. 2 and Table. 2.

Table 2: Growth of slum households in Bhubaneswar ULB from 1971 to 2019

\begin{tabular}{|c|c|c|c|c|c|c|c|c|}
\hline Year & ULBs & $\begin{array}{l}\text { No } \\
\text { Poc }\end{array}$ & $\begin{array}{l}\text { Total } \\
\text { Popul }^{\mathrm{n}}\end{array}$ & $\begin{array}{l}\text { Slum } \\
\text { Popl }^{\mathrm{n}}\end{array}$ & $\begin{array}{l}\text { Slum } \\
\mathrm{HH}\end{array}$ & $\begin{array}{c}\text { Slum } \\
\text { Popul }^{\mathrm{n}}\end{array}$ & $\begin{array}{c}\text { Spaces } \\
\text { availabilty }\end{array}$ & $\begin{array}{l}\text { Slum rehabilitation } \\
\text { status }\end{array}$ \\
\hline 1971 & Bhubaneswar NAC & 7 & 105491 & 23 & $\sim 6000$ & $\sim 24000$ & within city & was not important \\
\hline 1981 & Bhubaneswar (M) & 23 & 219419 & 24 & $\sim 13000$ & $\sim 52000$ & within city & Importance given \\
\hline 1989 & Bhubaneswar (M) & 70 & 387893 & 22.4 & 17175 & 86901 & within city & Importance given \\
\hline 1991 & Bhubaneswar (M) & 86 & 411542 & 23.1 & 21003 & 95000 & less space & Importance given \\
\hline 1993 & Bhubaneswar(MC) & 101 & 458840 & 25.5 & 24318 & 117000 & less space & Importance given \\
\hline 1999 & Bhubaneswar(MC) & 145 & 600734 & 33.3 & 30000 & $\approx 200000$ & less space & $\begin{array}{l}\text { Slums damaged in } \\
\text { Super cyclone }\end{array}$ \\
\hline 2001 & Bhubaneswar(MC) & 145 & 648032 & 30.9 & 18048 & 71413 & $\begin{array}{l}\text { Hor. growth } \\
\text { difficult }\end{array}$ & $\begin{array}{l}\text { Many slums dented in } \\
\text { SC-1999 }\end{array}$ \\
\hline 2011 & Bhubaneswar(MC) & 377 & 843402 & 36.7 & 42277 & 163983 & $\begin{array}{l}\text { Vert. } \text { growth } \\
\text { started }\end{array}$ & $\begin{array}{l}\text { Slum rehabilitation } \\
\text { given stress }\end{array}$ \\
\hline 2019 & Bhubaneswar MC) & 436 & 939818 & 33.7 & 80665 & 301611 & $\begin{array}{l}\text { Vert. growth } \\
\text { rampant }\end{array}$ & $\begin{array}{l}\text { Slum demolition } \\
\text { started in the city }\end{array}$ \\
\hline
\end{tabular}

NB: Vrtl: Vertical, Horzl: Horizontal, NAC: Notified Area Council, M : Municipality, MC: Municipal corporation, Populn: Population, Poc: Pockets, HH: Households

Source: IIHS 2017[7], BMC web site data

The Bhubaneswar Municipal Corporation has identified a total of slum dwellers in the city are 308614dwelling in 436 slum pockets (projected population 929717 in year 2018) and total household units are 60,612.The paucity of planned houses has encouraged the exploding population to go for unauthorized occupancy in slums. Out of slum pockets (436), BMC has identified recognized 320 (73\%), unauthorized 116 (27\%) and authorized were only one (Rout NR 2008). The total slum population is 304140 persons in 80,665 house holds. Presently $\approx 30 \%$ of the population of BBSR are living in slums of low grade lining standards.BMC has identified 229 numbers of authorized, unauthorized and identified slums in 67 wards of BMC which has been extended to 81numbers; Industrial (Ward Nos: 68 \& 69) and others are rural villages in the suburban's in Fig 3 and Table 3. 
From Squatter Slums to Modelled Dwellings in Anthropocene: Bhubaneswar, India

Table 3: Zone wise slum pockets/population/ total population of BBSR city (Source: BMC)

\begin{tabular}{|c|c|c|c|c|c|c|c|c|c|c|c|}
\hline $\begin{array}{l}\text { Ward } \\
\text { No }\end{array}$ & $\begin{array}{l}\text { Populat } \\
\text { ion }\end{array}$ & $\begin{array}{l}\text { Slum } \\
\text { Popul }^{\mathrm{n}}\end{array}$ & $\begin{array}{l}\text { Poc } \\
\text { kets }\end{array}$ & $\begin{array}{l}\text { Ward } \\
\text { No }\end{array}$ & $\begin{array}{l}\text { Popul } \\
\text { tion }\end{array}$ & $\begin{array}{l}\text { Slum } \\
\text { Popul }^{\mathrm{n}}\end{array}$ & Pockets & $\begin{array}{l}\text { Ward } \\
\text { No }\end{array}$ & $\begin{array}{l}\text { Populati } \\
\text { on }\end{array}$ & $\begin{array}{l}\text { Slum } \\
\text { Populn }\end{array}$ & $\begin{array}{l}\text { No } \\
\text { Pockets }\end{array}$ \\
\hline \multicolumn{4}{|c|}{ Bhubaneswar North zone } & \multicolumn{4}{|c|}{ Bhubaneswar South West zone } & \multicolumn{4}{|c|}{ Bhubaneswar South East zone } \\
\hline 1 & 47574 & 4261 & 3 & 15 & 25825 & 3030 & 3 & 28 & 19491 & 5196 & 5 \\
\hline 2 & 13110 & 4334 & 5 & 22 & 9869 & 12042 & 13 & 29 & 18295 & 3959 & 5 \\
\hline 3 & 16505 & 1208 & 5 & 23 & 11003 & 9983 & 16 & 30 & 21009 & 1917 & 3 \\
\hline 4 & 16185 & 4327 & 19 & 24 & 11195 & 2740 & 4 & 31 & 14581 & 4206 & 6 \\
\hline 5 & 23446 & 4992 & 8 & 25 & 14797 & 2828 & 4 & 32 & 7840 & 2656 & 4 \\
\hline 6 & 14060 & 1163 & 3 & 27 & 13244 & 6578 & 4 & 33 & 11638 & 3374 & 3 \\
\hline 7 & 13932 & 666 & 2 & 37 & 10078 & 2281 & 5 & 34 & 10379 & 6302 & 6 \\
\hline 8 & 11344 & 3364 & 4 & 38 & 9616 & 1562 & 6 & 35 & 9259 & 4605 & 7 \\
\hline 9 & 21744 & 7409 & 13 & 39 & 13375 & 1864 & 5 & 36 & 10924 & 839 & 2 \\
\hline 10 & 10491 & 5849 & 14 & 46 & 9439 & 5030 & 11 & 40 & 13320 & 5446 & 13 \\
\hline 11 & 12781 & 1541 & 3 & 47 & 13923 & 6780 & 10 & 41 & 9786 & 7379 & 11 \\
\hline 12 & 20230 & 4734 & 6 & 48 & 8643 & 4670 & 6 & 42 & 16539 & 4398 & 8 \\
\hline 13 & 17607 & 3173 & 3 & 49 & 9352 & 1470 & 5 & 43 & 9185 & 1470 & 5 \\
\hline 14 & 14951 & 7494 & 10 & 50 & 13630 & 2878 & 4 & 44 & 10011 & 936 & 3 \\
\hline 16 & 20230 & 19610 & 2 & 51 & 11228 & 3601 & 4 & 45 & 10871 & 1673 & 8 \\
\hline 17 & 17607 & 8314 & 15 & 52 & 8492 & 2970 & 5 & 53 & 13687 & 8838 & 9 \\
\hline 18 & 14951 & 1962 & 9 & 62 & 741 & 7027 & 6 & 54 & 15955 & 1610 & 5 \\
\hline 19 & 13508 & 2504 & 3 & 63 & 3850 & 3139 & 6 & 55 & 12249 & 1404 & 3 \\
\hline 20 & 13589 & 11513 & 3 & 64 & 2946 & 8436 & 11 & 56 & 10679 & 6151 & 10 \\
\hline 21 & 15427 & 11086 & 10 & 65 & 1208 & 7935 & NA & 57 & 10724 & 2651 & 3 \\
\hline 26 & 11117 & 10271 & 5 & 66 & 5843 & 2529 & 7 & 58 & 14736 & 3584 & 9 \\
\hline $\mathbf{T}$ & 47574 & 4261 & 145 & $\mathbf{T}$ & 198858 & 99373 & 135 & 59 & 16515 & 1884 & 8 \\
\hline \multirow{4}{*}{\multicolumn{8}{|c|}{$\begin{array}{l}\text { (BMC has identified } 229 \text { numbers of authorized, unauthorized and identified } \\
\text { slums in } 67 \text { wards of BMC which has been extended to } 81 \text { wards based on } \\
\text { Industrial (Ward Nos: } 68 \text { and } 69 \text { as industrial and other suburban's). }\end{array}$}} & 60 & 14509 & NA & 6 \\
\hline & & & & & & & & 61 & 13522 & 1985 & 6 \\
\hline & & & & & & & & 67 & 11707 & 2529 & 8 \\
\hline & & & & & & & & $T$ & 327411 & 84992 & 156 \\
\hline
\end{tabular}

Both skilled and unskilled work forces, labourers along with students and patients from all over the states and from eastern India flow to the city regularly.

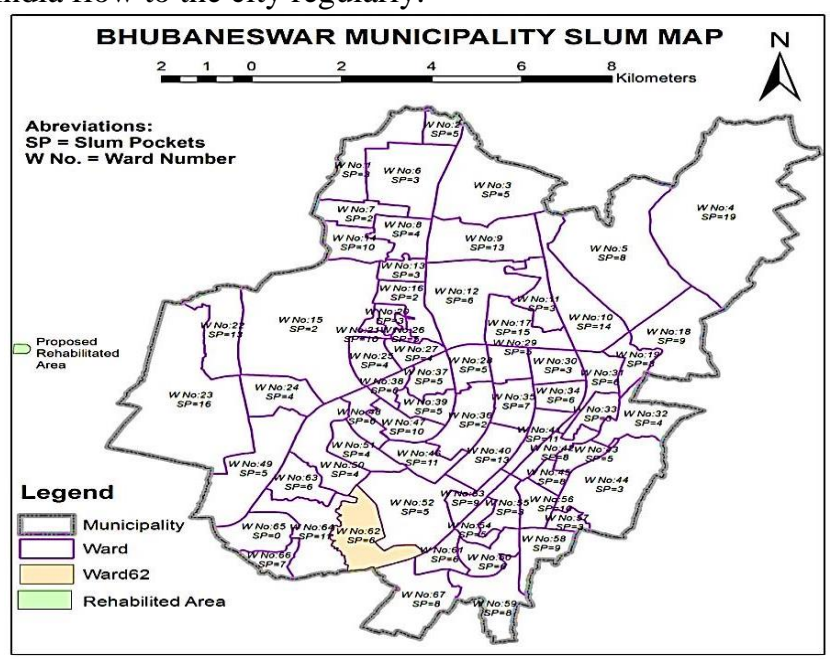

Fig.4: Zone wise slum pockets/population with total population of Bhubaneswar city

After smart city declaration, Bhubaneswar shall be made a slum-free City and necessary plan is chalked out by JNNURM/RAY, PMAY, NUHM (National Urban Health Mission), PRAYAS, UPA (Urban Poverty Alleviation Cell), SBA (Swachha Bharat Abhijan), FSSM (faucal sludge and septage management) and AMRUT (SLIP) shall be implemented by the BMC. Municipal Commissioner I/C of
Slums/Urban Community Development/Planning under the Slum-free City Cell being coordinated by NRSC, ISRO and other agencies shall coordinate with other agencies to make the target achievable. The details of slum statistics of Bhubaneswar city is in Fig. 4, Table 3.

\section{REVIEW OF LITERATURE:}

Rout NR, 2008[8]studied slum colonies development till 2001 (data oversized) and the heal of the slum dwellers in Bhubaneswar. Das VA 2017[9]reported that the extent of satisfaction of slum dwellers have proved that though they are poor, hard up, socially downtrodden, culturally subjugated, politically passive, disheartened, abused but spiritually strong and satisfied in the slum community environment. The Census 2011[5]data reveals that the city and it's outgrowth comprises of 885363 out of which major people are Hindu(95.21\%) followed by Muslims 3.29\% and Buddhist's (0.92\%). Sorate R.R., et al., 2014[10] emphasized Aluform technology (Tunneling) and rapid walling) are effective methods for rehabilitation which reduces the time, price and resources of construction..

Anand G. et al., 2017[7]reported that BDA was formed in 1983 of area $135 \mathrm{~km} 2$ (67 wards), annexing parts os Khordha and Jatni area of $233 \mathrm{~km} 2$ at present with a master plan to join Cuttack city to form BBSR-Cuttack complex by 2030 joining BMC, BDPA Rural, 
Khorda and Jatani of area 419.10km2.Slum dwellers owning their housing land are $\approx 39.78 \%$ whereas $52.33 \%$ have constructed tenements or kuccha houses on encroached govt. lands. Government lands or staying in the rented houses within the slum areas,( about 78\% pucca and 22\% kuchha built) Pattanaik I, 2015[11] According to report given to Honorable High Court, Odisha there are 377 numbers of recognized slums within the greater BMC area, 99 slums are on own land and rest 278 are encroached landhttps://www.telegraph india.com /states/ odisha/twin-slums-under-court-scanner/cid/362176. There is diurnal/seasonal variation of SAT of Bhubaneswar, which greatly influence the zonal temperature variation od about 30C between present and pervious areas within 25 x $30 \mathrm{~km}$ creating an UHI (Swain D et. al., 2016)[12].

\section{The Study Area:}

The Kargil slum runs between the Bhubaneswar airport and east coast railways, covers an area of $18494.143 m 2$. Kargil Slum Area is under Bhubaneswar Municipality Corporation (BMC) Ward No- 62 (25 $2^{\prime} 0^{\prime \prime} \mathrm{N}$ lat. and $88^{\circ} 9^{\prime}$ $0 "$ E long.).Bhubaneswar was formed from a cluster of villages in 1950, and developed today to a smart city with population about one million. The Kargil Basti (Slum) in ward no 62, has developed over a past uninhibited literate quarry surrounding two water bodies lies in the SE zone of BMC. The Kargil slum has about 1200 slum houses giving shelter to about 7000 people. The slum people have inadequate access to minimum services like drainage water, electricity, roads and drainage system, health and education services, the basic need of the inhabitants of the Basti people in spite of NGO's or federal sustenance, poverty alleviation programmed, still persists.

\section{Need for Study:}

Bhubaneswar's constitutes old town which was in existence before the shifting of the capital; the planned capital city; and now the unplanned sprawl.. The BMC is spread over an area of $135 \mathrm{Km} 2$, covering 67 administrative wards with 885363 people(Census 2011). The slum' population was 163983 people (18.5 per cent).Population wise the most urbanized top five cities in Odisha are Khurdha (48.11\%), Jharsuguda (39.89\%), Sundargarh (35.50\%) Sambalpur (29.81\%), followed by Cuttack (27.94\%), According to 2019data the slum dwellers in BBSR city are 308614 (33.74\% of total people) ranked4thamong Indian cities (Greater Mumbai 54.1\%, Faridabad 46.5\%, Meerut 44.1\%) Sawhney U, (2013)[13].From 2011 to a recent study on the slum dwellers of Bhubaneswar (during 2019) has increased from $18.5 \%$ to $34.01 \%$ which is alarming. After declaration of BBSR as a smart city, it demands the metropolis should be made slum free. Due to the location of Kargil slum, land value it ranks the first priority to plan for alternative settlement for these slum dwellers.

\section{METHODOLOGY}

The methodologies adopted in the study are the in situ reconnaissance survey of the slum dwellers in Kargil slum and their present socio-economic status, sex ratio, environmental status, health issues. The various survey works undertaken are the advanced Survey (Satellite Survey, Field survey using Total station), primary data collection by field survey ( House no., Ownership Status, Designation, Sex, Income), analysis of primary and secondary data
(Source: EWS schemes). The survey that shall be conducted are Reconnaissance survey, Preliminary Survey, Location Survey) for the resettlement Place. The laboratories works shall be taken up are the water, soil investigation Fig 5 .

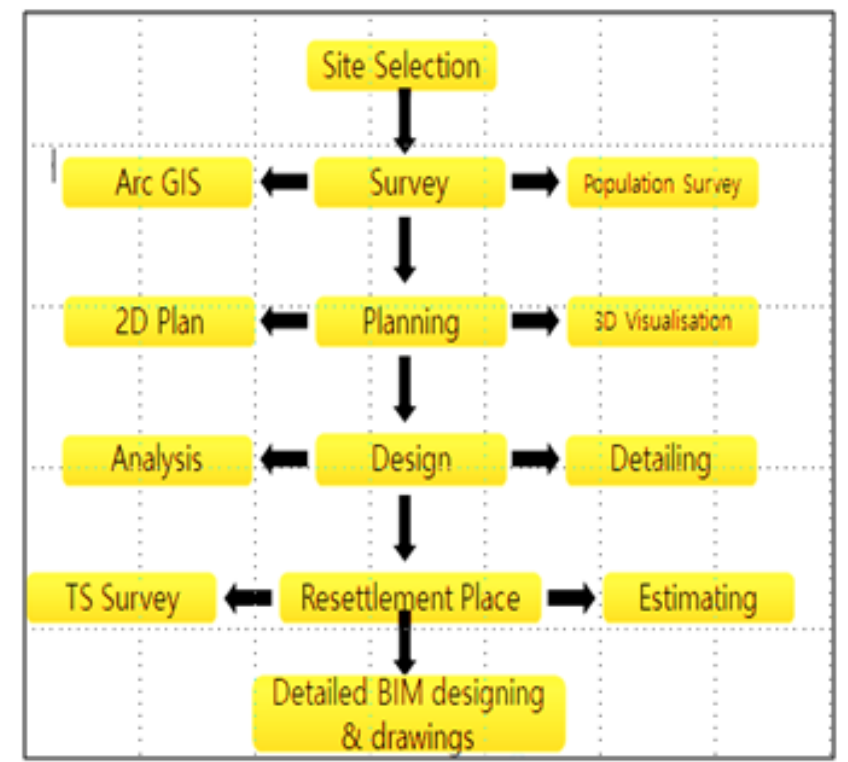

Fig 5: The flow chart of the resettled housing scheme for
Kargil slum dwellers of Bhubaneswar

The different Autodesk works has been taken and designed with Building Information Modelling (BIM) by Auto Cad, E-tabs, Safe, Arc GIS, \#-D modelling by Sketch-up, block-wise Design ( Beam, Column, Slab, Stair, Footing) etc in 25 Blocks (1000 units) to be designed over 6.23 Acre. The schedule for the work is to be chalked out. The estimate is to be prepared at the current scheduled of rate to find out cost of each unit so that resettled people can have roof over their head.

\section{In-situ Satellite Survey:}

Before proceeding for the sample survey, the satellite survey was done by downloading the slum area map and was geo referenced. The GIS map of the slum area is prepared by using the Q-GIS Software. The Kargil area was initially developed due to two water bodies within the slum (Fig-7).The prima facie of the formation of the slum is due to its nearness to the Railway station, bus stops and well communicated to all the business hubs. The murky atmosphere is found in the Kargil slums $\left(20^{\circ} 14^{\prime} 15^{\prime} \mathrm{N}\right.$, $\left.85^{\circ} 49^{\prime} 00^{\prime} \mathrm{E}\right)$ shown in Fig 1. The Shanty settlement (Ward No. 62) is presently developed from 1970's covering an area 11.82 Ac constituting 1035 Household (HH) Fig 6. 


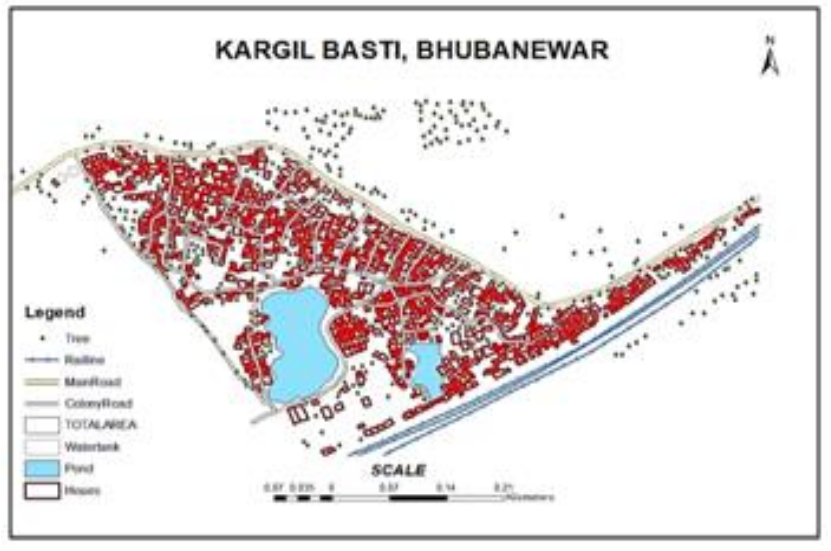

Fig 6: Geospatial map of Kargil slum at Bhubaneswar, Odisha

\section{A. Sample Survey Kargil Slum Area:}

In spite of BMC restrictions the numbers of houses are increasing as the location is in the heart of the city. A population survey was conducted based on the slum habitats of 1027 families considering population, sex, numbers of houses, income, profession and their base of owning the land as variables. A detailed sample survey in the field was done for 1029 families in 1017 nos. of houses in an area in $18494.143 \mathrm{~m}^{2}$. The highest numbers are found the masons/carpenters followed small business community (Hawkers) and the road side food plaza owners. As urban slums add to the process of urbanization and main workers are skilled labour class namely Masons or carpenters and plumbers that constitute the Kargil slum Fig 7.

The major portions of the slum dwellers are from housing sector and male labours are dominating, the sex ratio in the slum area as per present sample survey in 2019 indicates the male female ratio is 53\%: $47 \%$. Some families, who are homeless and financially stable can shift to the planned satellite area within the smart city either on sharing cost, concessional cost or cost relief basis. The slum dwellers are mostly migrants from inside and the outside states. The annual average income of 998 families out of 1027 families surveyed are less than 8lakhs and the rest 29 families have more than 8lakhs/ annum. The present housing scheme envisages the dwellers are from EWS group and are not capable to construct their own house at the peak land and construction cost of the city

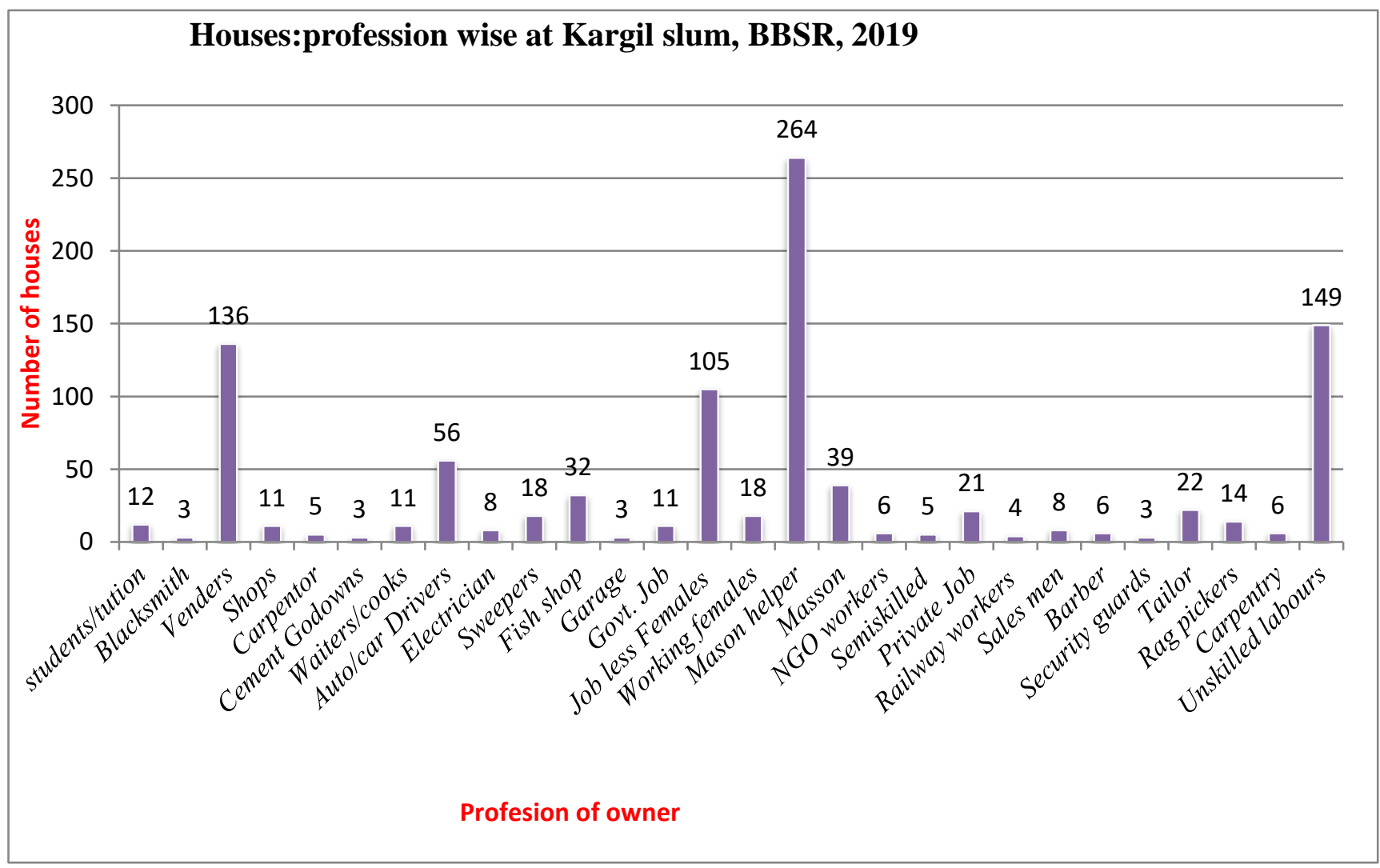

Fig.7: Result Of Population Survey, The Families Residing In The Kargil Slum

\section{B. Resettlement options:}

Alternate resettlement colonies are needed in the out skirt of the township. After selection of four sites towards SW zone, some barren lands were located from the google map. The suitability of an alternate area from these four scrub lands were selected .Among them, Ghangapatna area is befitting as it is just adjacent to $\mathrm{NH} \mathrm{16,} \mathrm{outskirt} \mathrm{of} \mathrm{the} \mathrm{city,} \mathrm{and}$ surrounded by many multistoried building and satellite cities. 

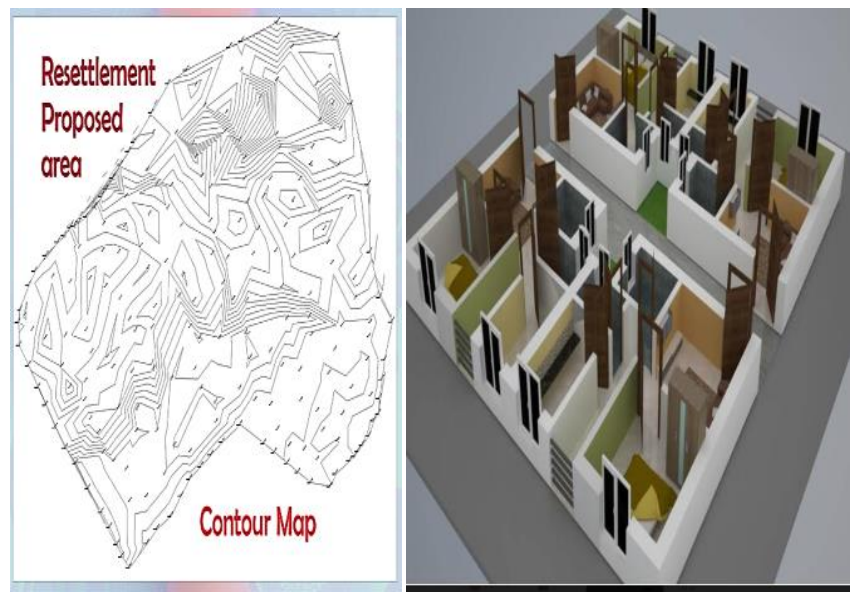

Fig. 8: Contour plan with a 3-D view of one unit proposed Resettlement area at Ghangapatna

An alternate housing scheme has been structured to scale up the delivery of civil amenities and provision of all utilities and basic services to slum dwellers including security of occupancy at affordable prices, better housing, health, water supply, and sanitation by ensuring them assured value-added life style, education, health and social security. The rehabilitation of the dwellers of Kargil slum area has been selected to shift to the Ganga Patna area for the safety of the International Airport and to protect highly Government land of towering value. The newly selected place is nearest to the Revenue Officers Training Institute and about $15 \mathrm{Km}$ from the city.

\section{Reconssiance Survey:}

The proposed area was surveyed in details with total station with subsidiary contour interval - 5 meter and the major contour interval of 10 meter. The contour map of the area is prepared Fig 8.

\section{Primary Soil Data Exploration:}

The soil samples from the area were collected and laboratory and in-situ tests were conducted and the soil test results are in Table 4.The soil of the resettlement site is suitable for foundation of high rise buildings of $\mathrm{G}+4$ (Height $>24 \mathrm{~m}$ )

\section{Geography:}

Geographically the area lies in Eastern Ghats hills range with $5-15 \mathrm{~m}$ literate rock as capping over country rocks of Athagarh formation and 1-2 $\mathrm{m}$ of forum as over burden. There is scanty bushy vegetation of tropical savanna climate and classified as Aw (wet \& dry climate tropical) as per Köppen and Geiger exists in the area Mishra S. P. 2019[14].

\section{Seismology:}

The land lies in the earth quake zone II and lies in the south of the Mahanadi shear zone and the chance of earth quake is less. In past the area had got mild tremors of magnitudes in ritcher,s scale (RS) were 1982 (5.5 RS), 1986 (4.4 RS), 2014 (6.0 RS), 2015 (5.8 RS).

\section{Meteorology:}

The average rainfall is found to be $1306.51 \mathrm{~mm}$ (1979 to 2019) and the highest maximum and minimum temperature recorded were $46.50 \mathrm{C}$ and $8.00 \mathrm{C}$ respectively. The area gets occasional hailstorms, winds from thunder squalls and cyclones slamming Odisha coast.

Hydrology: Terrain wise the area is in hill slope and leeward side of the Khandagiri Hills. No large water body or major drain exists in the area. The pre and post-monsoon geo- hydro logical maps indicate that the GWL lies 5-10m mbgl and average yield is <3-5lps (CGWB-2013)[15].

Table 4: Status of Soil at Rehabilitation (Ghangapatna)

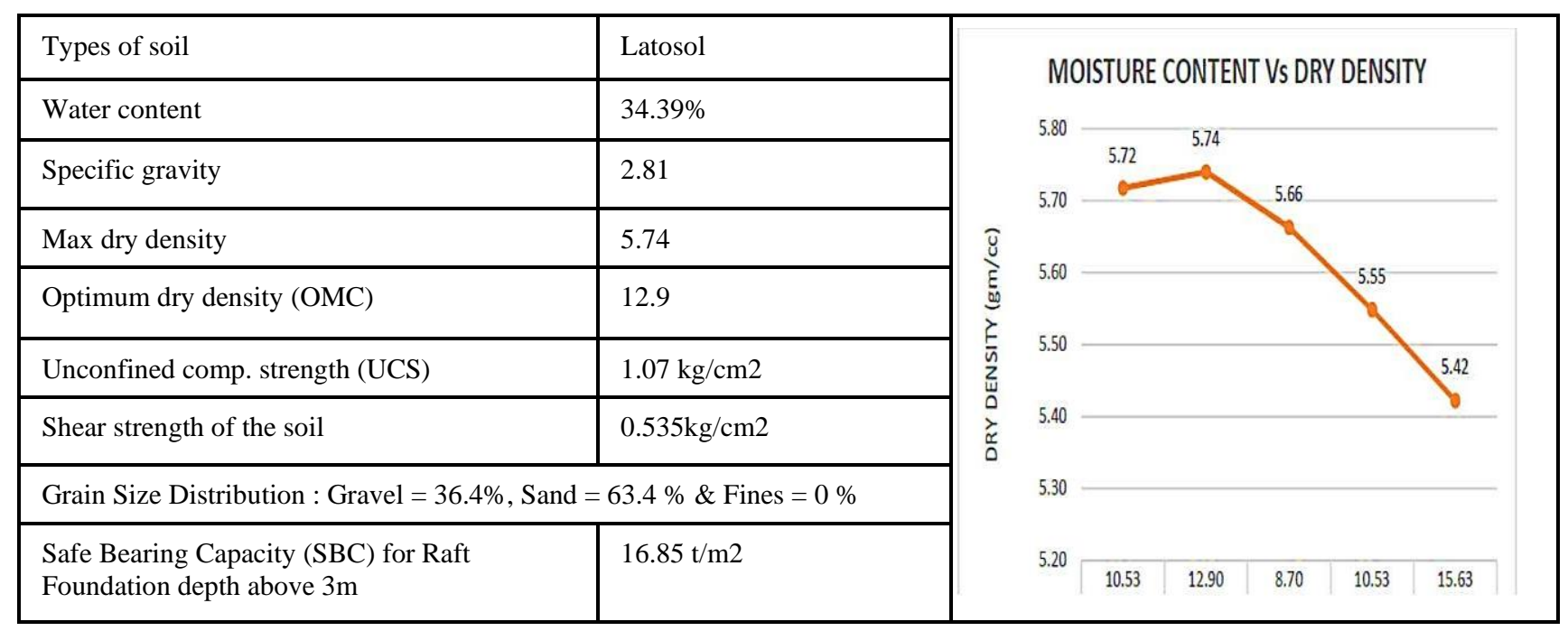

\section{Ground Water Quality:}

Some physio-chemical characteristics of the ground water were examined in the laboratory for physical and chemical properties from deep well and the results are in Table -5 
From Squatter Slums to Modelled Dwellings in Anthropocene: Bhubaneswar, India

Table 5: The physico-chemical properties of ground water under Ghangapatna housing scheme

\begin{tabular}{|c|c|c|c|c|c|c|c|c|c|c|c|}
\hline Place & Block & Dist. & Well & $\mathrm{pH}$ & $\begin{array}{l}\text { EC m- } \\
\text { hos } / \mathrm{cm}\end{array}$ & $\begin{array}{l}\text { TDS } \\
\mathrm{mg} / 1\end{array}$ & $\begin{array}{l}\mathrm{Ca}+, \\
\mathrm{mg} / 1\end{array}$ & $\begin{array}{l}\mathrm{Mg}++, \\
\mathrm{mg} / 1\end{array}$ & $\begin{array}{l}\mathrm{Na}+, \\
\mathrm{mg} / 1\end{array}$ & $\begin{array}{l}\mathrm{K}+, \\
\mathrm{mg} / 1\end{array}$ & $\mathrm{Cl}-, \mathrm{mgl}$ \\
\hline 1 & 2 & 3 & 4 & 5 & 6 & 7 & 8 & 9 & 10 & 11 & 12 \\
\hline G Patna & BBSR & Khurda & $\overline{D W}$ & 5.54 & 135 & 99 & 14 & 4.86 & 6.1 & 3.1 & 14.18 \\
\hline $\begin{array}{l}\mathrm{SO4--,} \\
\mathrm{mg} 1\end{array}$ & $\begin{array}{l}\mathrm{CO} 3-- \\
\mathrm{mg} /\end{array}$ & $\begin{array}{l}\mathrm{HCO3-}, \\
\mathrm{mg} /\end{array}$ & $\begin{array}{l}\text { F-, } \\
\text { mg1 }\end{array}$ & $\begin{array}{l}\mathrm{NO3}, \\
\mathrm{mg} /\end{array}$ & $\begin{array}{l}\mathrm{Fe}, \\
\mathrm{mg} / 1\end{array}$ & $\begin{array}{l}\mathrm{Ca}, \\
\mathrm{meq} / 1\end{array}$ & $\begin{array}{l}\text { Tot } \\
\text { cations }\end{array}$ & $\begin{array}{l}\text { T. +Anio } \\
\mathrm{n}(\text { An })\end{array}$ & $\begin{array}{l}(\operatorname{col} 20- \\
\operatorname{col} 21)\end{array}$ & $\begin{array}{l}\mathrm{Na} \\
\mathrm{Cl}\end{array}$ & TDS/EC \\
\hline 13 & 14 & 15 & 16 & 17 & 18 & 19 & 20 & 21 & 22 & 23 & 24 \\
\hline 0 & 0 & 36.6 & 0 & 17.97 & 0.755 & 0.7 & 1.445 & 1.29 & 0.057 & 0.66 & 0.73 \\
\hline
\end{tabular}

From the lab tests it is instituted that the tube well water is not harmful for human portability except the concentration of Iron.

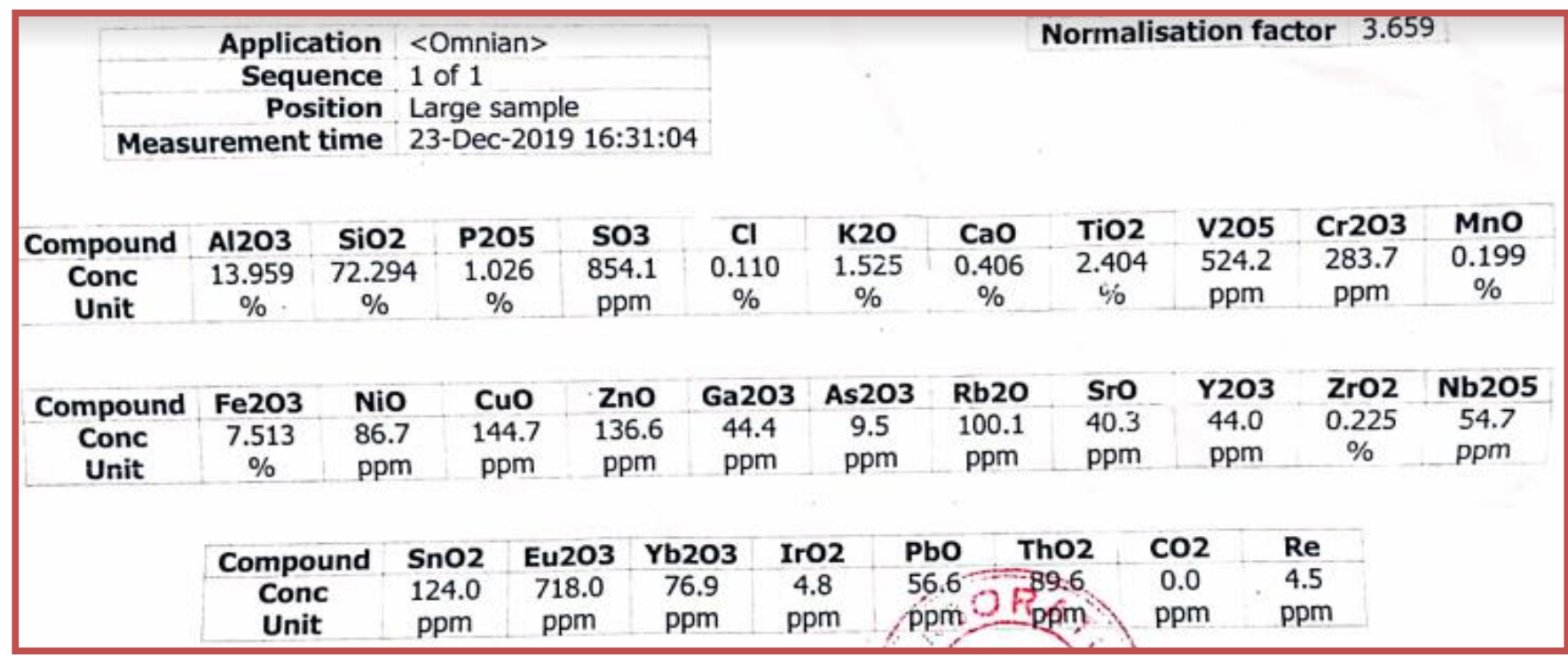

Fig. 9: Oxides of heavy metals, metalloids, rare earth metals present in soil at Ghangapatna

Hence to find the concentration of Heavy and toxic metals it is felt necessary to conduct by X-Ray Fluorescent (XRF) spectroscopy and the observation results are given in Table 6:The water contaminants as metal oxides are Aluminum (Al), Iron (Fe), Ammonia (NH3), Arsenic (As), Barium (Ba), Cadmium (Cd), Chromium (Cr), Copper (Cu) and others like Fluoride (F), Bacteria/Viruses, Lead (Pb) and Mercury (Hg). The Oxides of radioactive elements are Radium ( $\mathrm{Ra})$, Selenium (Se), Silver (Ag) and Uranium (U) (https://www.wqa.org/learn-about-water/common-contamin ants) and the ground water quality is poor for the for the flora and fauna Das and Mishra S. P, 2019[16] Since the soil/ water from deep wells of the area contains mostly oxides of heavy metals, the water source may be taken from alternate Municipal water supply scheme.

\section{Overall Planning:}

The barren land of 6.23Ac is selected to construct 1000 units to accommodate 25blocks. The satellite image of the Ghangapatna area was down loaded. That image was subjected to digitations process followed by buffering to get the buffered image as a final output. The houses, ponds, main/colony road, vegetation etc were located. The resettled site plan is in Fig 10.

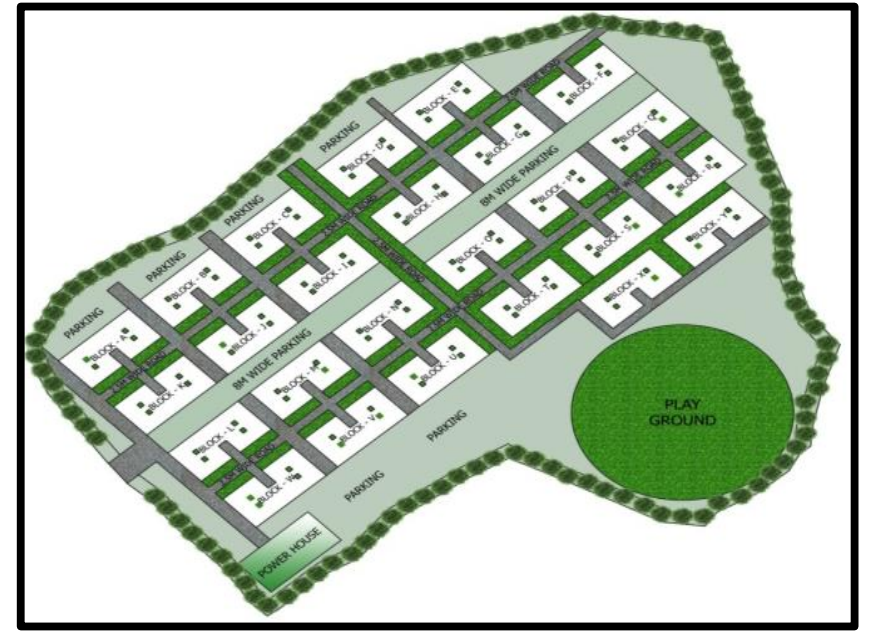

Fig. 10: Overall site plan of the proposed resettlement colony at Ghangapatna

\section{Tenement Plan:}

It is planned that the single unit shall have carpet area = $21.64 \mathrm{~m}^{2}$ and the super buildup area $=30.20 \mathrm{~m}^{2}$

Published By:

Blue Eyes Intelligence Engineering 


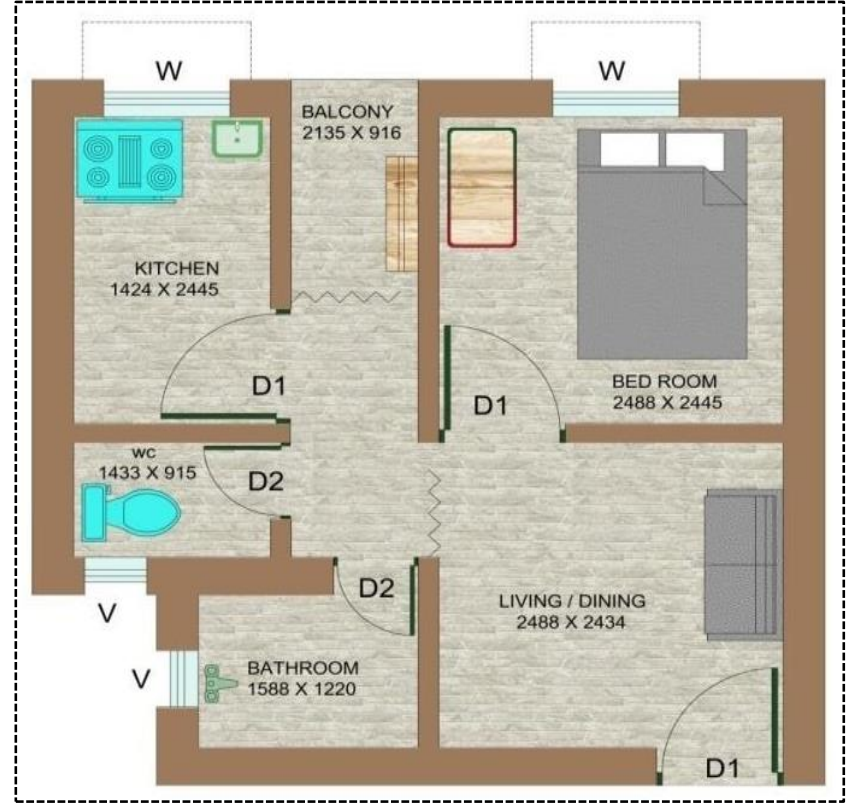

Fig. 11: The single tenement and block plan in proposed resettled village

The openings shall have sizes for doors $\left(d_{1}\right)=915 \times 2134$ $\mathrm{mm},\left(\mathrm{d}_{2)}=610 \times 2134 \mathrm{~mm}\right.$, windows $(\mathrm{w})=915 \times 2100 \mathrm{~mm}$ and ventilators $(\mathrm{v})=610 \times 610 \mathrm{~mm}$.

\section{Load details:}

The dead load, live load, wind load and seismic loads provided during BIM modelling are Dead Load $=6 \mathrm{Kn} / \mathrm{m} 2$, Live Load $=5 \mathrm{Kn} / \mathrm{m} 2$, Seismic Zone $=$ II, Z factor $=0.1$, Load Combination $=\quad 1.5 \quad(\mathrm{DL}+\mathrm{LL}), \quad=1.2(\mathrm{DL}+\mathrm{LL}+\mathrm{ELX})$ $=1.2(\mathrm{DL}+\mathrm{LL}-\mathrm{ELZ}) \quad=1.5(\mathrm{DL}-\mathrm{ELX}) \quad=1.5(\mathrm{DL}-\mathrm{ELZ})$ $=0.9 \mathrm{DL}-1.5 \mathrm{ELX} \quad=0.9 \mathrm{DL}-1.5 \mathrm{ELZ}$.

\section{Dead and Live loads:}

1. Self-weight of the individual components.

2. Self-weight of the beam \& column
a. $0.5 \mathrm{~m} * 0.3 \mathrm{~m} * 1 \mathrm{~m} * 25 \mathrm{kn} / \mathrm{m}^{3}$
b. $3.75 \mathrm{kn} / \mathrm{m} 3$ (taken by software by default)
c. Self-weight of the slab=152m*25kn/m $/ \mathrm{m}^{3} @=3.8 \mathrm{kn} / \mathrm{m}^{2}$
d. Floor finishes $=1 \mathrm{kn} / \mathrm{m}^{2}$
e. Furniture \& equipment loads $=1 \mathrm{kn} / \mathrm{m}^{2}$
f. Total dead load given $=5.8 \mathrm{kn} / \mathrm{m}^{2}$
g. Live load $=3 \mathrm{kn} / \mathrm{m}^{2}$ As per IS-875 Part 2

\section{Seismic Load:}

The impact of earth quake on structure depends on the stiffness of the structure, stiffness of soil media, height and location of the structure. According to Annex E,IS-1893(part -1):2002, Bhubaneswar belongs to zone II. Zone factor , $\mathrm{Z}=$ $0.16, \mathrm{~h}=$ total height of the building, Time period in $\mathrm{x}$ direction, $\mathrm{T}=(0.075 * \mathrm{~h})=0.75$.

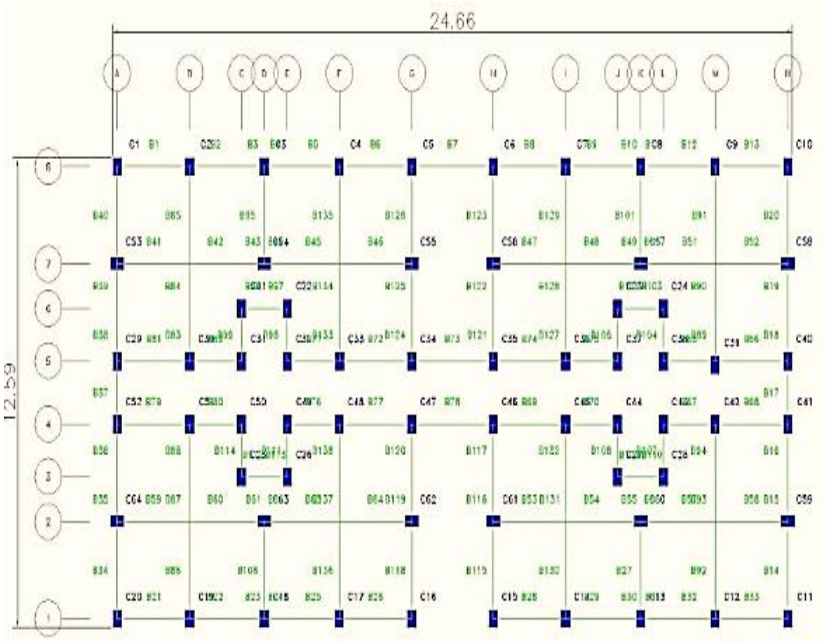

Fig 12: Layout of a block of the proposed block of the resettlement colony at Ghangapatna

\section{Wind Load Calculation:}

Wind analysis is done based on recommendation given in IS-875(part 3) ,1987. The design wind speed can be calculated as : $\mathrm{Vz}=\mathrm{Vb} * \mathrm{~K} 1 * \mathrm{~K} 2 * \mathrm{~K} 3$ :Where: $\mathrm{Vb}$ - basic wind speed in $\mathrm{m} / \mathrm{s}, \mathrm{Vz}$ - design wind speed at any height $\mathrm{z}$ in $\mathrm{m} / \mathrm{s}$, $\mathrm{K} 1$ - risk factor, K2- factor to obtain design wind speed depending upon height of the building \& terrain, K3topography factor, DalglieshW. A., et al., 2019[17]

\section{Design and Detailing:}

Foundation: As the bed of the site is continuous laterite formation, provide mat foundation to the structure as the bearing capacity is very week. SBC is 16 ton $/ \mathrm{m} 2$ and the building axial load is $881 \mathrm{kn}$, so mat foundation has been proposed.

\section{Column Details:}

The size of the column to be provided as per BIM modeling are $0.300 \times 0.460 \mathrm{~m}$, with stirrup is $0.230 \times 0.380 \mathrm{~m}$, $0.380 \mathrm{~m}, 0.220 \times 0.230 \mathrm{~m}$.

The reinforcement details are total $=12 \# 20 \mathrm{~mm}$ q and Stirrups=10mm qp@200mm c/c.

\section{Beam details:}

The sizes of the beams as per the BIM model are $0.380 \mathrm{X}$ $0.500 \mathrm{~m}$ with stirrups of $0.280 \times 0.410 \mathrm{~m}$ and the reinforcement details are top Bar $=2 \# 18 \mathrm{~mm}$ qp, bottom bar $=2 \# 18 \mathrm{~mm}$ q , Mid bar $=2 \# 10 \mathrm{~mm}$ q and Stirrups $=10 \mathrm{~mm}$ q @ 180mm c/c, 2 legged.

\section{Slab Details:}

Concrete slabs are common structural elements of contemporary constructions, consisting of flat, horizontal surface made of cast concrete. Steel reinforced slabs, typically between 100 and $500 \mathrm{~mm}$ thick, are most often used for floors and ceilings. Ultimate moment $=2 \mathrm{kn}-\mathrm{m}$, bar-bend details=8 mm \# @ 200 mm C / C, Clear Cover = 15 mm and Thickness of slab $=150 \mathrm{~mm}$ 


\section{From Squatter Slums to Modelled Dwellings in Anthropocene: Bhubaneswar, India}

\section{E. Architectural view of the project:}

On visualization, the top view, the front view and the aesthetic view of the proposed housing scheme for resettlement of Kargil slum to Ghangapatna shall be as in Fig 13 (a) to Fig 13(d).

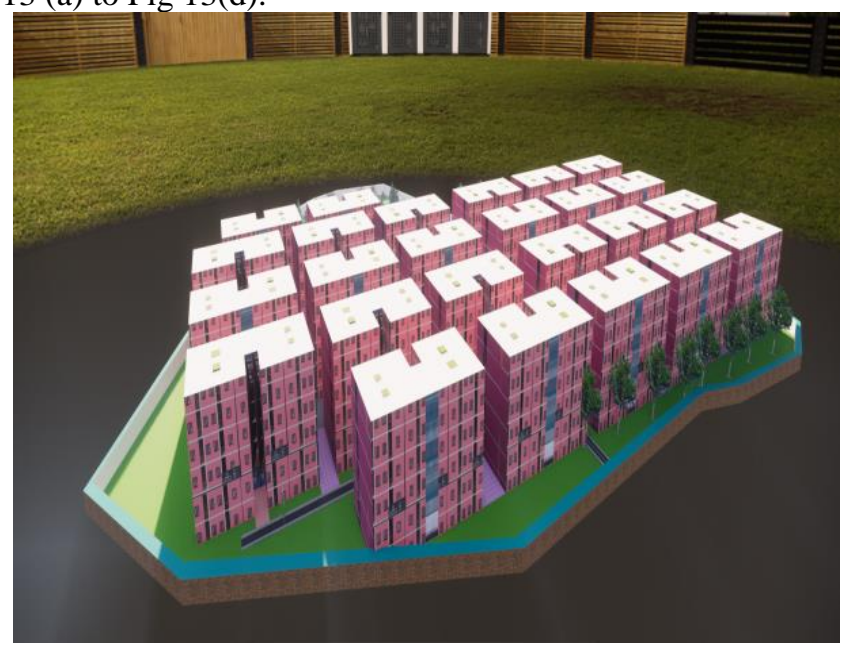

Fig 13(a): Top view of the proposed Apartment

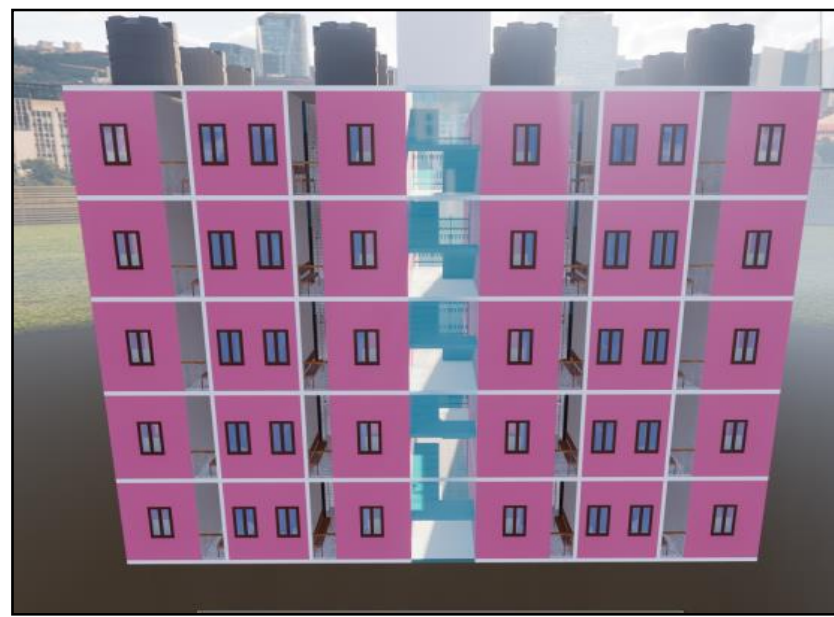

Fig 13 (b): Front view of the Apartment

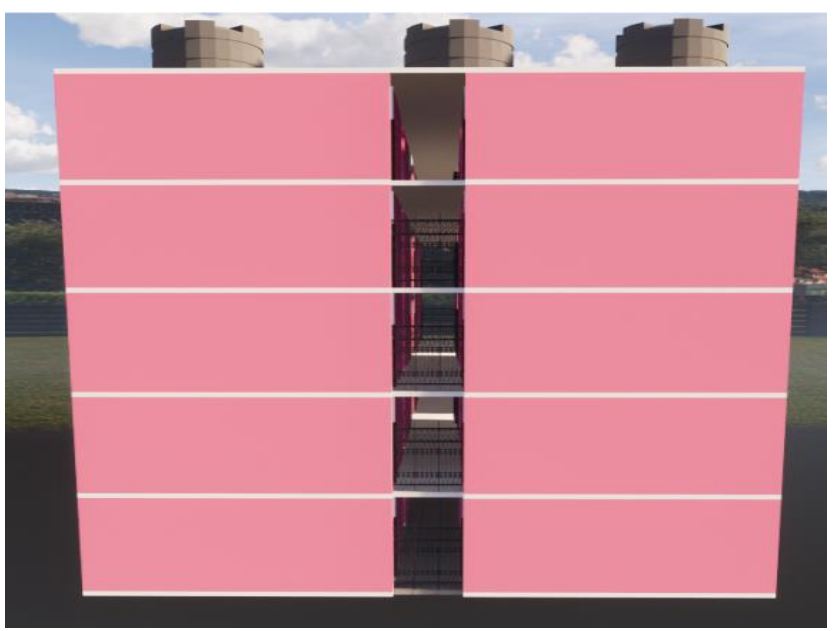

Fig 13(C): Side View of the Housing project

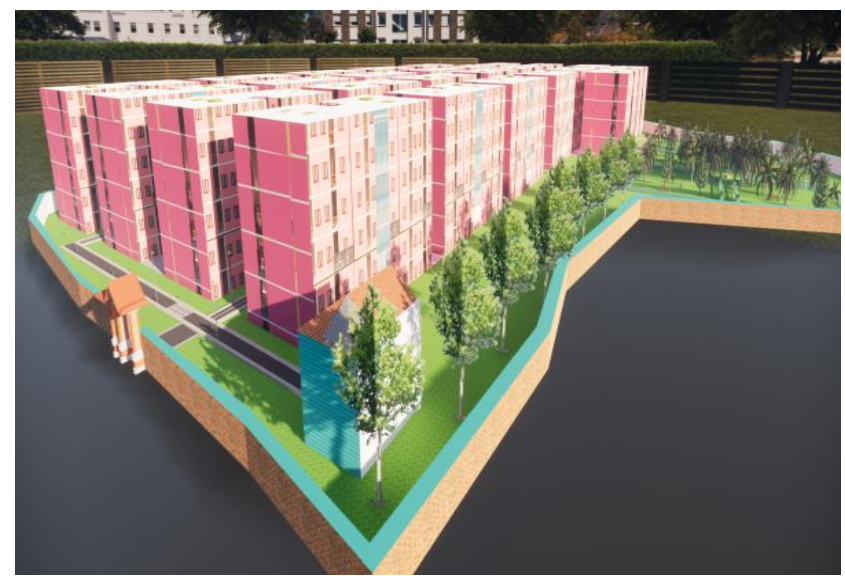

Fig 13(d): Aesthetic view of the project

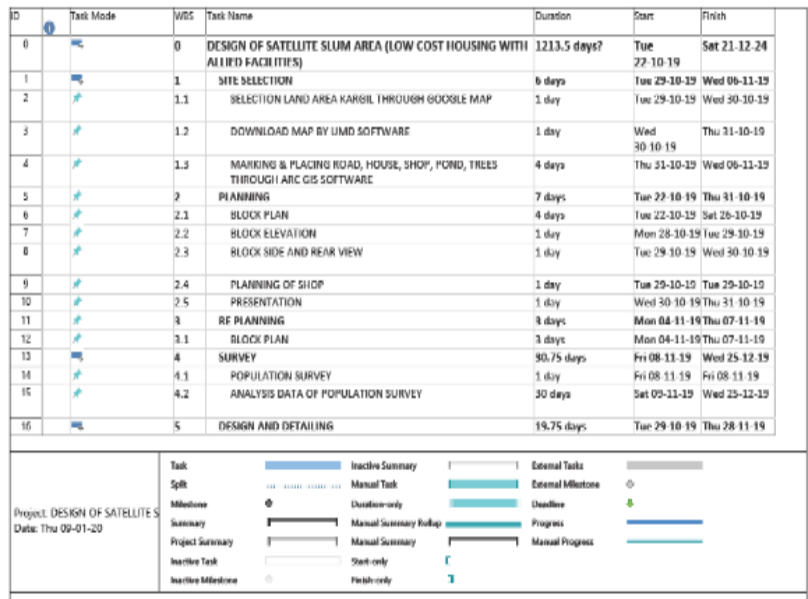

Fig 14: Work Schedule for the Proposed housing scheme

The work schedule has been prepared taking the help of Ms Office and Ms Project software considering the workforce, materials, machines and the cash flow and the total project duration was found to be 3 Years 4 Months. The schedule is in Fig 14.

\section{Estimate cost of the project:}

The total cost for the project was estimated unit wise using AutoCAD and E-tabs and the cost involved segment wise like foundation, ground floor, $1^{\text {st }}$ floor to $4^{\text {th }}$ floor with lofts, water tanks and staircase etc. for each unit comes to 440.3millions in INR, the land development costs shall be 2.9 million INR including road, boundary wall, Road, parking, and overall cost shall be about 440million INR. The individual dwelling unit per family shall be only 440K INR which is a small amount for the each family under installment payments.

\section{Discussion:}

Information Education Communication (IEC) activities are taken up in to consideration for the proposed settled area to see that slum dwellers shall live in healthy and hygienic conditions to provide social awareness and community development with the help of $\mathrm{CBO} / \mathrm{NGO}$ 's parallel to different states of India, The s recent ordinances, the Odisha Land Rights to Slum Dwellers Ordinance, 2017, assures land to the urban poor in municipalities and NACs.

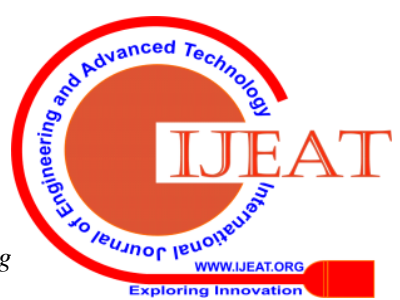


On SWOT ANALYSIS, it is inferred that, the strength shall be provision of colonial living, Pucca buildings, and basic amenities like safe drinking water, electricity, and sewerage system which they were lagging and leading to quality and safe living with harmony and IEC activities. The opportunities shall be entrée to further income generating resources, organizational culture inculcation, improving colonial lifecycle standards. The weakness are income shall mismatch their living standard, affecting zoning, time waste in transport, improper disposal of solid wastes, more people in less space endangering peace and tranquility. The threats shall be muscle and money power shall invite attrition.

\section{CONCLUSION}

From the above study, we conclude that even though government is taking so many efforts to improve the quality of life of people living in the slum, at certain level government is still failing to achieve its goals. Good housing, water supply, sanitation and health these basic needs are not being fulfilled. Due illiteracy people in the slums are not getting proper employment resulting into deprivation in their quality of life. This issue is to be addressed at micro level and therefore there is a need to frame a systematic program.So, the aim of the project is to give a suitable life and other facilities. The suitable measures shall improve their quality of life. So similar resettlement plans can be made to provide basic requirements of the quality life at a subsidized cost to the slum dwellers so that the slum clustered city shall be slum less.

\section{ACKNOWLEDGMENT}

We express our heartiest acknowledgement to Mr. Raj Kumar Jena, Md. Asraf Khan and Ms Ananya Stitinanda during field survey and other pertinent works of the project.

\section{REFERENCES}

1. Nallathiga R. K., Girkar P., a Sapra S.,2019, Planning Slum Rehabilitation/Redevelopment Projects: Evaluation and Learning from Mumbai, III International Conference on Construction, Real estate, Infrastructure and Project Management, G Korgaonkar and J Koner (Eds), 'Real Estate Development', Research \& Publications Department, National Institute of Construction Management Research, Pune, pp 11 30

2. Hindman M., Lu-Hill O., Murphy S., Rao S., Shah Y., Zhu Z., 2015, Addressing Slum Redevelopment Issues in India, Dow Fellows Program Coordinator, $\quad$ pp- $\quad 1-63, \quad$ http://sustain ability.umich.edu/media/files/dow/Dow-Slum-Redevelopment-Indiaf

3. More M. J.,2017, Slum Rehabilitation, Master's thesis, Civil Eng. Dept., BharatiyaVidyabhavan's, Sardar Patel college of Eng., Andheri (west), Mumbai, pp1-28

4. Parveen Kumar, 2016, Slums in India: Results from Census, 2011, Journal ofEnv. and Social Sciences, Vol-3(1), pp-03

5. Govt of Odisha, 2016, State preparedness for NUHM programme: PP-1-4,http://www.nrhmorissa.gov.in/writereaddata/Upload/Document s/NUHM

6. Government of Odisha, 2017, THE ODISHA LAND RIGHTS TO SLUM DWELLERS ACT, 2017, The Odisha Gazette Notification No. 1652, Oct. 16, 2017

7. Anand G. and Deb A.2017, Planning, 'Violations', and Urban Inclusion:A Study of Bhubaneswar, YUVA and the Indian Institute for Human Settlements, IIHS. ND-Delhi.1-38, http://iihs.co.in/knowledge -gateway/ wp-content/uploads/2017/11/Bhubaneswar

8. Rout NR, (2008), Slum Growth in Bhubaneswar: A Problem or Solution?, ITPI Journal, 5(4), 59-64, www.itpi.org.in

9. Das V. A., (2017), Life satisfaction factors of slum dwellers in and Applied Sc., 3(12), Dec.-2017 bhubaneswar city, odisha - an exploratory study, Int. Jr. of Management

10. Sorate R.R., Dhiman A., Murnal A., Nimbalkar M., Dere N., Tiwari V.,2014, lum Rehabilitation with Fast Track Techniques, IOSR Journal of Mech. and Civil Eng., JMCE) Vol.-11 (3), PP 27-32

11. Pattanaik I., (2015), Impact of migration on women: A case study in slum dwellers in Bhubaneswar city of Odisha, Int. Jr. of Multidisciplinary Res. and Dev., 2(2): 420-425

12. Swain D., Roberts G. J., Dash J., Vinoja V., Lekshmi K.. and Tripathy S. 2016, Impact of rapid urbanization on the microclimate of Indian cities: a case study for the city of Bhubaneswar, Land Surface and Cryosphere Remote Sensing III, edited by Reza K., Ganju A., Rajawat A. S., Chen J. M., Proc. of SPIE Vol. 9877, pp- 01-07, SPIE, doi: 10. $1117 / 12.2228111$

13. SawhneyUpinder, (2013), Slum population in India: Extent and policy response, International Journal of Research in Business and Social Science, IJRBS;.2 (1), 47-56,

14. Mishra S. P., Nayak S. Pr, Mishra S., Siddique M., Sethi K. C., 2019, GIS And Auto Desk Modeling For Satellite Cities around Bhubaneswar, International Journal of Innovative Technology and Exploring Engineering (IJITEE) ISSN: 2278-3075, Volume-8 (11), September 2019, PP- 297-306

15. Ministry of Water Resources, Govt of India, 2013, Ground water information Booklet, of

Khurda district, Central Ground Water Board, South Eastern Region Bhubaneswar, pp:1-24

16. Das A., Mishra S. P., Pattanayak G D, Sethi K. C., 2019, Geo-bio chemistry of wetlands in laterite mines, the Chilika catchment, Odisha: GIS study and XRF spectroscopy appraisal, Int. J. Adv. Res.Vol: 7(1),pp- 688-714, DOI URL:http://dx.doi.org/10.21474/ IJAR 01/837

17. Dalgliesh W. A.,Schriever W. R., (2019), Wind pressures on buildings, NRC Publications Archive, National research council, Canada pp-1-6,https://nrc-publications.canada.ca/eng/view/accepted/?id=2610d 377

\section{Important Links}

- https://www.youtube.com/watch?v=pZo1tKbEHGs https://www.youtube.com/watch?v=9NBMeQPhS $\mathrm{E}$

- http://iihs.co.in/knowledge-gateway/wp-content/upl oads/2017/11/Bhubaneswar-Final.pdf

- $\quad$ https://www.researchgate.net/publication/25262701 6 Slum_Growth in_Bhubaneswar_A_Problem_or Solution

- https://youtu.be/zADj0k0waFY

- https://www.youtube.com/watch?v=LPIMPCswlzw

- $\quad$ https://umbc.org.in/index.php/page?name=kargil-b asti

- http://iihs.co.in/knowledge-gateway/wp-content/upl oads/2017/11/Bhubaneswar-Final.pdf

- https://smartcities.data.gov.in/catalog/housing-andslum-population-bhubaneswar

- $\quad$ https://www.census2011.co.in/census/city/270-bhu baneswar.html

\section{AUTHORS PROFILE}

Saswat Mishra, Final Year Scholar, National Institute of Construction Management and Research, New Delhi

Dr. Siba Prasad Mishra, Asso. Prof. in Deparment of Civil, Centurion University of Technology and Management, Odisha, India.

Dr. Mohammed Siddique, Faculty in Department of Mathematics and Associate Dean in School of Applied Sciences, Centurion University of Technology and Management, Odisha, India. 